sert plateaus between the Andes and the sea, they crossed the open ocean to Guatemala. Over Central America they met and passed the hosts of migrant birds who were flying northward to overtake the North American spring. Perhaps the most interesting part of the story to naturalists is their leisurely move northward as spring moved northward from the Gulf of Mexico to Saskatchewan.

As they crossed our own prairie, the ecstasy of their love making made them oblivious to humans and to fear, they fed closely behind the farm machinery in the field. A

\section{A BOOK REVIEW}

\section{By FRANK H. BRAZIER}

"Sea-Birds" by James Fisher and R. M. Lockley (Houghton Mifflin Co., Boston, 1954).

Aside from strictly $r$ eference books, there are a few volumes which ought to grace the shelves of every naturalist's library, whether he be casual, dilettante or professional. Most of these books, not being professional texts, are to be found in public libraries. Some of these would be Rachel Carlson's "The Sea around Us", Dr. N. J. Berrill's "Sex and the Nature of Things", Edgar Anderson's "Plants, Man and Life", Francois Bouliere's "The Natural History of Mammals", Konrad Lorenz's "King Solomon's Ring", Charles Darwin's "Origin of Species", H. G. Wells' "The Science of Life" and M. W. de Laubenfels "Pageant of Life Science". No doubt there are others but the foregoing come readily to mind. To this illustrious company I have no hesitation in recommending that "Sea-Birds" be added. If this book was simply a book about the sea-birds of the North Atlantic we could afford it casual interest, but it is much more than that, although the authors modestly state: "We have paused in field-work simply to offer this book as a stimulant. We intend it as no more." Stimulant indeed it is, but to more than ornithologists.

It shows how many sciences contribute to the one science - geology, ecology, biology, oceanology, meteorology, etc., all assist ornithology, on the terms. trigger-happy farmer spotted them. A shot gun blasted out its pellets of death, and the female was no more. The curlew headed north in silence alone - once again he defended his territory - for it must be kept in readiness for the female his instinct told him soon would come.

In June, this year, Mr. Bodsworth's novel was purchased by Reader's Digest for inclusion in the Autumn volume of Reader's Digest Condensed Books. This is the first time that a book by a Canadian author has been accepted for use in a Condensed Book Volume.

so the ornithologist must understand the other non-ornithological factors. The description of the structure of the North Atlantic, and its currents and climate, in relation to the bird life there could be used as a pattern by a Saskatchewan ornithologist in relating the Province's geology and climate to its bird life. In addition, the tables, diagrams and unique map-nets illustrate. how the subject information can be best presented.

The chapter on Evolution of birds is particularly detailed and interesting, especially when discussing areas of origin of the various bird families. The fact that the North Atlantic has not been the area of origin of any important group of sea-birds will be accepted by geologists as pertinent comment on the Wegener Theory of Continental Drift. As the California Gull (Larus californicus) and the Herring Gull (Larus argentatus) both occur in Saskatchewan it is interesting to note that they are actually subspecies which, with others, form circumpolar chains.

In the chapter entitled "Sea-Bird Numbers and Man", the melancholy tale of the extinction of the Great Auk (Alca impennis) makes grim reading, as does the account of the inroads made by the millinery trade

The first half of the book examines certain phases of sea-bird study such as migrations and movements, navigation, social and sexual behaviour, 
which is the most valuable half of the book insofar as Saskatchewan readers would be concerned, although the latter half of the book, dealing with the birds themselves, is no less interesting. Because we do have gulls, the chapter on them is particularly interesting, especially the notes on the large gulls of the genus Larus, which is represented here. Unless we have given the matter some study, we do not generally realize that these gulls in their nesting colonies, or "gulleries", according to our standards, exhibit the most disgusting behaviour, which is of course the most natural behaviour according to the gulls' standards. Robbery, murder and cannibalism, even within the limits of the family, seem to be the dominant controlling factor of their numbers. Natural hehaviour it may be, but the picture given by the authors of a parent gull swallowing one of its own young, and then later regurgitating it for a meal for its brother or sister is something less than charming. Interesting as they may be, it will be difficult for me to learn to love a Larus gull. I would be interested to learn if the same behaviour is characteristic of Larus gulls on inland nesting sites.

There are a number of thoughtprovoking passages, e.g. "From the study of the ecology of animals we are learning that their numbers are controlled primarily by the amount of food they can get, and only secondarily by their parasites and predators; and parasites are probably more important than predators. But there are exceptions to this; and the chief one is when the predator is man (another is when new predators are introduced through his agency)."

The reader of "Sea-Birds" cannot fail to gain a better understanding of birds as a whole (not to mention the sea-birds themselves, and the basin of the North Atlantic) and the delicately balanced, intricately interlocked pageant of life on earth in which everything, including birds and ourselves, daily plays a part.

If at all possible, attend the Society's Annual Meeting in the new Museum.

See inside of back cover.

\section{Museum Assistant}

Dr. Róbert W. Nero of Madison, Wisconsin, has been appointed assistant director of Saskatchewan's new museum of natural history at Regina.

Dr. Nero was curator of the zoology department museum, University of Wisconsin at Madison from 1949 to 1955 . He studied at that institution, obtaining his Ph.D. degree in zoology there this year, and has also done professional research in ornithology and archaeology. During the last war he served with the American armed forces in the Pacific.

In addition to assisting the director with the administration of the museum, Dr. Nero will be directly responsible for supervising and directing the muscum's education and extension program. He will also organize field activities for the collection of specimens for displays, supervise preparation of these exhibits and help with designing displays.

Dr. Nero is 33 years of age, is married and has three children.

\section{Sight Record of Black Necked Stilt}

\section{By PETER McLELLAN, Arcola}

"Having lived on the prairie since 1888, I seldom now see a new bird, but on May 20th I saw three Blacknecked Stilts. They came flying up a creek; one lit on a willow fence post beside me and the other two waded fifty feet away.

The upper surface of their wings was more of a dark slate color than the black back, and the white underparts became cream colored on the lower abdomen, but the pink legs were even pinker than most illustrations.

All my life I have been telling the kids that a long-legged wader on a fence picket can be nothing but an upland plover, now I shall have to say that if it has pink legs it is a stilt."

(Note: This beautiful species once bred as far north as New Jersey and (Continued on Page 22) 